\title{
Retrograde Selective Washing of Upper Tract
}

National Cancer Institute

\section{Source}

National Cancer Institute. Retrograde Selective Washing of Upper Tract. NCI Thesaurus.

Code C159887.

Lavage of the ureter and renal pelvis with collection of the fluid to sample cells for

pathology. 